\section{Australian Journal of \\ Crop Science}

AJCS 13(03):452-457 (2019)

doi: 10.21475/ajcs.19.13.03.p1462

\title{
The physiological quality of yellow passion fruit (Passiflora edulis Sims. f. flavicarpa Deg.) seeds with different water content placed in a cold chamber room and environmental conditions
}

\author{
Paula Aparecida Muniz de Lima ${ }^{1}$, Khétrin Silva Maciel ${ }^{2}$, Rodrigo Sobreira Alexandre ${ }^{3}$, José Carlos Lopes ${ }^{4 *}$ \\ ${ }^{1}$ Postgraduate Program in Plant Production, Federal University of Espírito Santo (Universidade Federal do Espírito \\ Santo), Alegre, Espírito Santo, Brazil \\ ${ }^{2}$ Center for Training in Agroforestry Sciences and Technologies, Federal University of Southern Bahia, Brazil \\ (Universidade Federal do Sul da Bahia), Itabuna, Bahia, Brazil \\ ${ }^{3}$ Department of Forest Sciences, Federal University of Espírito Santo (Universidade Federal do Espírito Santo), \\ Alegre, Espírito Santo, Brazil \\ ${ }^{4}$ Department of Plant Production, Federal University of Espírito Santo (Universidade Federal do Espírito Santo), \\ Alegre, Espírito Santo, Brazil
}

\section{*Corresponding author: jcufes@bol.com.br}

\section{Abstract}

Seed quality is extremely important for the crop production system, and storage conditions are important to preserve this quality. The objective this study was to evaluate the physiological quality of yellow passion fruit seeds with different water contents placed in a cold chamber room $\left(4^{\circ} \mathrm{C}\right)$ and in a natural laboratory environment $\left(25 \pm 2^{\circ} \mathrm{C}\right)$ for a period of eight months $(240$ days). Passion fruit seeds were harvested in orchards of the southern region of Espírito Santo, with water content adjusted to $10 \% ; 14 \% ; 18 \%$ and $22 \%$, and placed in a cold chamber room and a natural laboratory environment. Germination, germination speed index, shoot and root length, fresh and dry mass of normal seedlings were evaluated. The experimental design was completely randomized, with two environments (cold chamber room and natural laboratory environment) and with a plot experimental arrangement subdivided according to time, with four replicates of 25 seeds within each environment. Yellow passion fruit seeds placed in a cold chamber room and natural environment with $14 \%$ of water content presented a higher physiological quality during eight months of storage. Yellow passion fruit seeds placed in a cold chamber room and natural environment presented maximum germination and vigour with 60 days of storage. Yellow passion fruit seeds exhibit orthodox behaviour, and should be stored at $14 \%$ of water content, in a cold chamber room and natural environment, without loss of viability and physiological quality over eight months, presenting maximum germination and vigour after 60 days storage, without the presence of pathogens.

Keywords: germination; Passiflora edulis Sims. f. flavicarpa Deg; storage; vigor.

Abbreviation: CC_cold chamber; DM_dry mass; FM_fresh mass; G_germination; GSI_ germination speed index; LAP_ length of aerial part; NE_natural environment; $\mathrm{RL} \_$root length.

\section{Introduction}

The passion fruit (Passiflora spp.) species belongs to the family Passifloraceae, and is found in tropical America. Brazil has a large number of such species from this family, of which more than 520 belong to the genus Passiflora. Among the edible and marketable species, yellow passion fruit (Passiflora edulis Sims. f. flavicarpa Deg.) is the best known and most cultivated in Brazil, accounting for $95 \%$ of the national production, with approximately $5 \%$ represented by purple passion fruit (Passiflora edulis Sims.) and sweet passion fruit (Passiflora alata Curtis) (Alexandre et al., 2009; lbge, 2011).

Seed quality is extremely important for the crop production system, and storage conditions are important to preserve this quality. Relative humidity is related to the seed moisture content, besides controlling different metabolic processes, while temperature influences the speed of the biochemical processes, and indirectly interferes in the seed moisture content (Carvalho and Nakagawa, 2012). Storage is an important method for the ex-situ conservation of genetic resources of plant species, aiming to conserve, improve or propagate the species (Caetano et al., 2012).

The physiological performance of yellow passion fruit seeds presents temporal variations which can cause seed dormancy (Martins et al., 2005). According to Souza et al. (2015), Passiflora ligularis Juss seeds freshly harvested from the fruit have a low germination percentage, and present a lower growth in height when compared to plants from stored seeds. 
During the seed storage period, relative humidity and temperature conditions, depending on the specific hygroscopic balance, will determine the maintenance of the physiological quality for a greater or lesser period (Borges et al., 2009). In this condition, there is a lower evolution of seed damage due to moisture, while in the natural environment, without temperature and relative humidity control, the seeds present lower physiological quality and greater evolution (Forti et al., 2010; Marques et al., 2014).

Proper storage depends on the good quality of the stored product. In order to obtain better seed quality, certain care should start in cultivation, avoiding mechanical damage, insect attack and a delayed harvest (Goldfarb and Queiroga, 2013). However, deterioration is an irreversible process (Popinigis, 1985), and it can be intensified by extending the seed storage period, even if it is done under refrigerated conditions (Cunha et al., 2009). The deterioration process of stored seeds is inevitable. With storage, seeds may lose their vigour, become more susceptible to stress during germination, and lose their ability to produce normal seedlings (Silva et al., 2014).

The objective of this study was to evaluate the behavior of yellow passion fruit seeds (Passiflora edulis Sims. f. flavicarpa Deg.) with different water content, placed in a cold chamber room and in a natural laboratory environment, without any relative humidity and temperature control for a period of eight months ( 240 days).

\section{Results and Discussion}

\section{Behaviour of yellow passion fruit seeds with different water} content

Yellow passion fruit seeds with $14 \%$ water content placed in a cold chamber room presented a higher germination percentage $(50.4 \%)$ and germination rate $(1.50)$, while the seeds with the highest water content, $18 \%$ and $22 \%$, recorded the lowest results $(3.6 \%, 0.10$ and $1.4 \%, 0.05$, respectively), with no significant difference between them. This is due to the level of deterioration that is closely associated with the seed moisture content; adding more moisture may promote a decrease in the seeds physiological quality (Marcos Filho, 2015) (Table 1). However, low seed moisture content decreases metabolic activity, deterioration occurs and physiological quality can be preserved for a longer period (Cardoso et al., 2012). The most evident physiological symptoms of seed deterioration are manifested during germination and early seedling development (José et al., 2010).

Regarding the seedlings' characteristics, there was no significant difference between the seedlings from seeds with $10 \%$ and $14 \%$ water content, both presenting higher averages when compared to the averages of $18 \%$ and $22 \%$ water content (Table 1).

In the natural environment, seeds with $14 \%$ water content presented a higher germination percentage and germination speed index (69\% and 3.72, respectively), while seeds with $22 \%$ water content presented lower averages ( $8.4 \%$ and 1.4 , respectively), seedlings from seeds with $10 \%, 14 \%$ and $18 \%$ did not present a significant difference, and seedlings from seeds with $22 \%$ had lower mean values (Table 1 ).

\section{Physiological quality of stored passion fruit seeds}

Seeds stored in a cold chamber with $18 \%$ and $22 \%$ water content and seeds stored in a natural laboratory environment, without relative humidity and temperature control, at $22 \%$ water content were not submitted to regression analysis because they presented low values in relation to those with a lower water content, corroborating the results observed in Jatropha curcas (Guzman and Aquino, 2009). According to Antunes et al. (2010), the seed moisture content is the factor that most interferes in the management of the physiological quality; therefore, the lower the water content, the greater the seed longevity. Queiroga et al. (2009) observed that $10 \%$ of water content conserved the physiological quality of the cotton seeds of the cultivars BRS Verde and CNPA 7H better. On the other hand, Marcos Filho (2015) states that the orthodox seeds moisture content generally should be $10 \%$ to $12 \%$, in order to store the seeds for six to eight months. However, in the present study, seeds with $14 \%$ water content placed in the cold chamber presented a higher germination percentage and GSI when compared to those with $10 \%$ water content (Figure 1).

During the storage period, an increase in the germination percentage and rate was observed after two months of storage, which may be due to the seed dormancy phenomenon, agreeing with Lima et al. (2010), who reported that yellow passion fruit seeds present postharvest dormancy, and break seed dormancy 30 days after storage Similarly, the storage of crambe seeds in the natural environment broke seed dormancy after the third month of storage (Bessa et al., 2015).

However, after 60 days of storage, there were oscillations in the germination values, and a tendency to decrease in the process speed over the storage period. The decline of physiological potential over the period is not restricted to a decrease in germination capacity, but this also becomes slower, accompanied by a decline in sensitivity to environmental adversities, characterizing the decrease of vigour (Marcos Filho, 2015).

Low-temperature environments favour and preserve seed viability, as verified in C. vernalis seeds (Vieira et al., 2008). Similarly, Catunda et al. (2003) observed that the refrigerated environment $\left(4{ }^{\circ} \mathrm{C}\right)$ preserved the viability of yellow passion fruit seeds for a period of 10 months of storage, and when packed in glass and polyethylene containers, the physiological quality was preserved for 90 and 180 days, respectively (Carlesso et al., 2008). Sunflower seeds tolerated storage for 180 days, at temperatures below zero and presented viability and preservation of vigour, with low seed deterioration, indicated by the low level of peroxides (Motta et al., 2014).

The highest mean germination rate was observed in seeds with $14 \%$ and $10 \%$ water content respectively, stored for two months, and the mean was $18 \%$ water content, also with two months of storage. However, Martins et al. (2005) state that the conservation of yellow passion fruit seeds stored in room temperature is favoured by the combination of $10 \%$ water content with a temperature of $20{ }^{\circ} \mathrm{C}$. The seeds stored in a natural environment, after two months, showed a significant increase in germination speed and percentage (Figure 2). After the storage period, there was a 
Table 1. Germination (G), germination speed index (GSI), length of aerial part (LAP), root length (RL), fresh mass (FM) and dry mass (DM) of Passiflora edulis Sims. f. flavicarpa Deg., with different water contents $10 \%$; $14 \%$; $18 \%$ and $22 \%$, after eight months (240 days) of storage in cold chamber (CC) and natural environment (NE).

\begin{tabular}{lccccccc}
\hline Environments & $\begin{array}{c}\text { Water } \\
\text { content (\%) }\end{array}$ & $\begin{array}{c}\text { G } \\
(\%)\end{array}$ & GSI & $\begin{array}{c}\text { LAP } \\
(\mathrm{cm})\end{array}$ & $\begin{array}{c}\text { RL } \\
(\mathrm{cm})\end{array}$ & $\begin{array}{c}\text { FM } \\
(\mathrm{mg})\end{array}$ & $\begin{array}{c}\text { DM } \\
(\mathrm{mg})\end{array}$ \\
\hline \multirow{4}{*}{$\mathrm{CC}$} & 10 & $36.4 \mathrm{~b}$ & $1.20 \mathrm{~b}$ & $5.28 \mathrm{a}$ & $4.63 \mathrm{a}$ & $76.13 \mathrm{a}$ & $6.48 \mathrm{a}$ \\
& 14 & $50.4 \mathrm{a}$ & $1.50 \mathrm{a}$ & $5.25 \mathrm{a}$ & $4.77 \mathrm{a}$ & $78.22 \mathrm{a}$ & $6.84 \mathrm{a}$ \\
& 18 & $3.6 \mathrm{c}$ & $0.10 \mathrm{c}$ & $3.06 \mathrm{~b}$ & $1.86 \mathrm{~b}$ & $44.29 \mathrm{~b}$ & $3.41 \mathrm{~b}$ \\
& 22 & $1.4 \mathrm{c}$ & $0.05 \mathrm{c}$ & $0.49 \mathrm{c}$ & $0.55 \mathrm{c}$ & $5.78 \mathrm{c}$ & $0.53 \mathrm{c}$ \\
\hline \multirow{3}{*}{$\mathrm{NE}$} & 10 & $58.4 \mathrm{~b}$ & $3.46 \mathrm{a}$ & $5.21 \mathrm{a}$ & $4.93 \mathrm{a}$ & $48.07 \mathrm{a}$ & $5.94 \mathrm{a}$ \\
& 14 & $69.0 \mathrm{a}$ & $3.72 \mathrm{a}$ & $5.21 \mathrm{a}$ & $5.23 \mathrm{a}$ & $49.82 \mathrm{a}$ & $5.71 \mathrm{a}$ \\
& 18 & $50.8 \mathrm{c}$ & $2.59 \mathrm{~b}$ & $4.27 \mathrm{a}$ & $4.07 \mathrm{a}$ & $46.67 \mathrm{a}$ & $5.57 \mathrm{a}$ \\
& 22 & $8.4 \mathrm{~d}$ & $1.40 \mathrm{c}$ & $0.80 \mathrm{~b}$ & $1.20 \mathrm{~b}$ & $8.84 \mathrm{~b}$ & $1.63 \mathrm{~b}$ \\
\hline
\end{tabular}

Means followed by the same letter, lowercase in the column, not differ by Tukey's test at the $5 \%$ probability level.

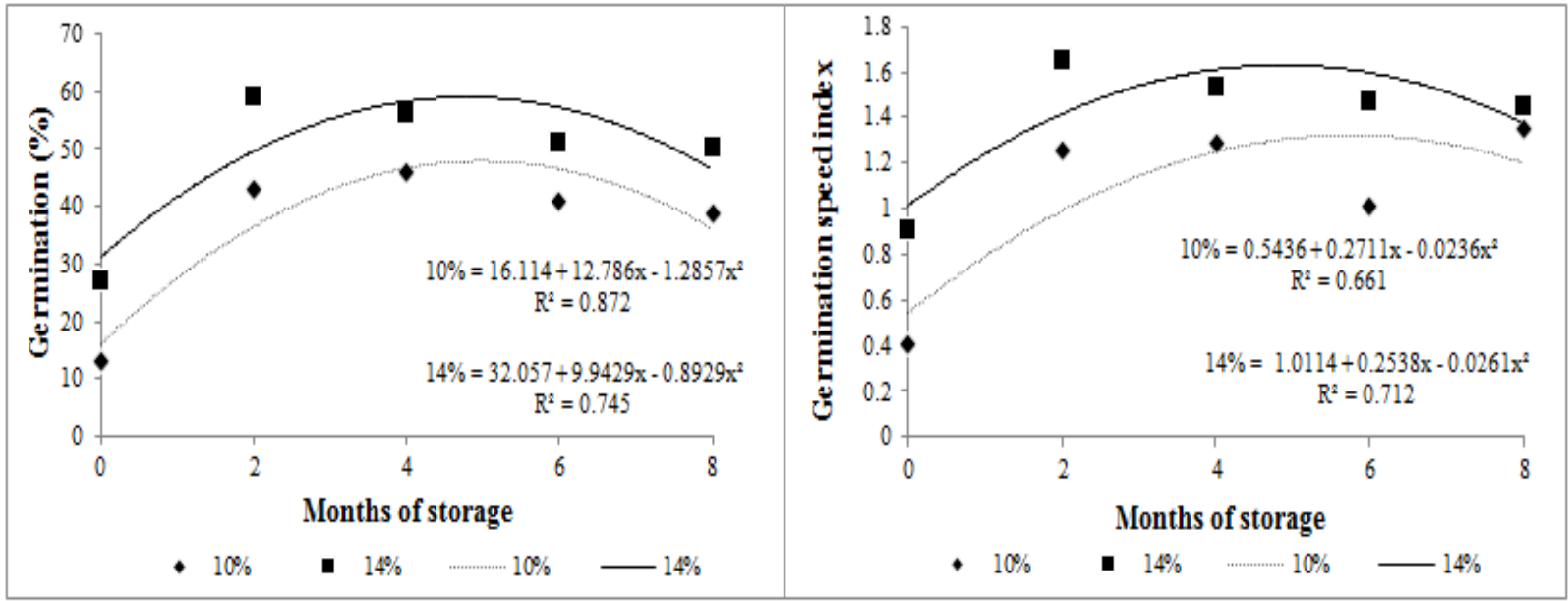

Fig 1. Germination, germination speed index of seeds of Passiflora edulis Sims. f. flavicarpa Deg., with water contents $10 \%$ and $14 \%$, stored for eight months ( 240 days) of in cold chamber.

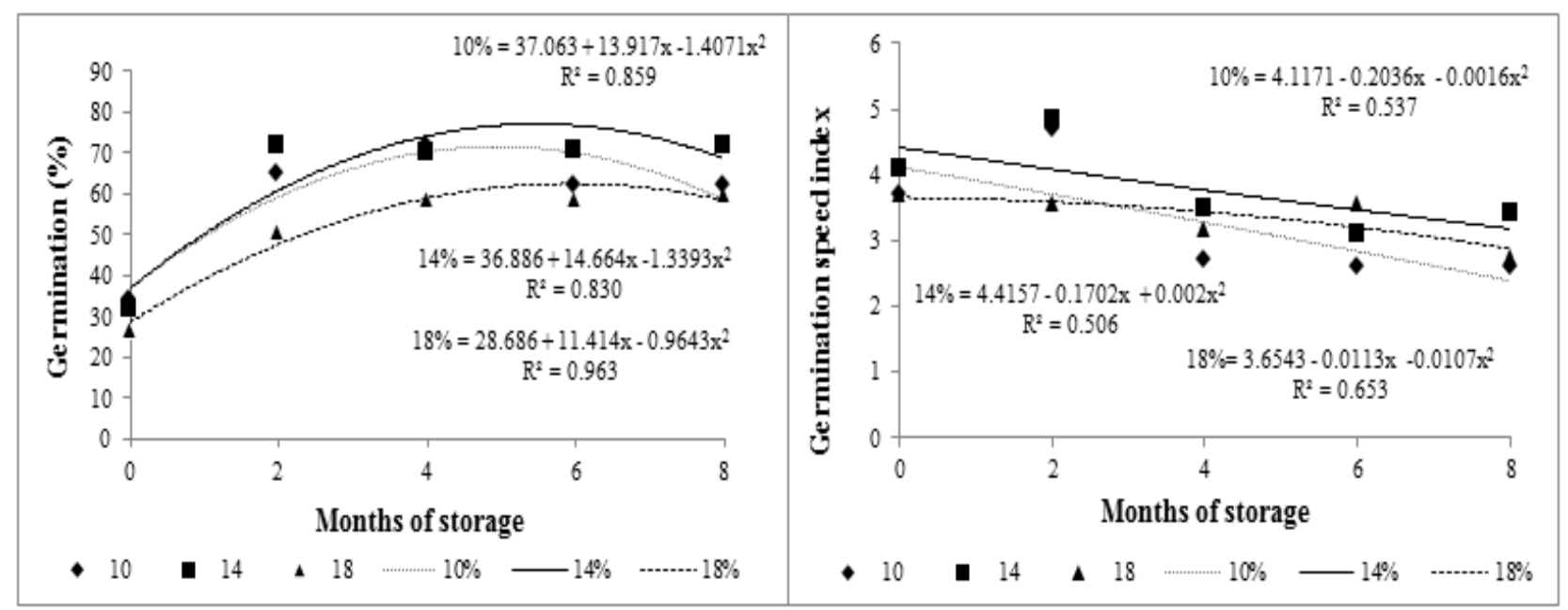

Fig 2. Germination, germination speed index of seeds of Passiflora edulis Sims. f. flavicarpa Deg., with water contents $10 \% ; 14 \%$ and $18 \%$, stored for eight months ( 240 days) of in and natural environment. 


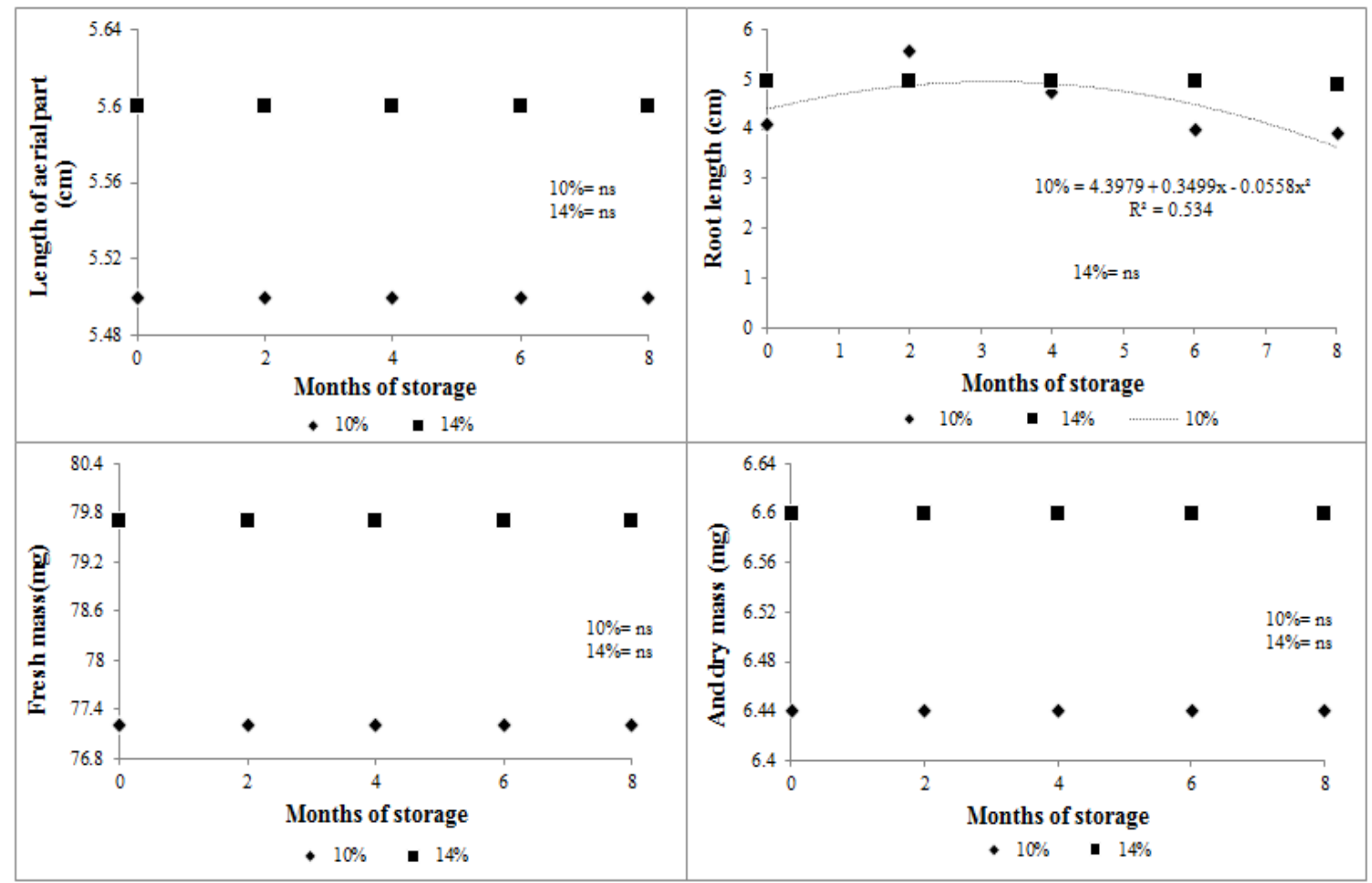

Fig 3. Length of aerial part, root length, fresh mass and dry mass of seedlings origining of seeds of Passiflora edulis Sims. $\mathrm{f}$. flavicarpa Deg., with water contents $10 \%$ and $14 \%$, stored for eight months ( 240 days) of in cold chamber.

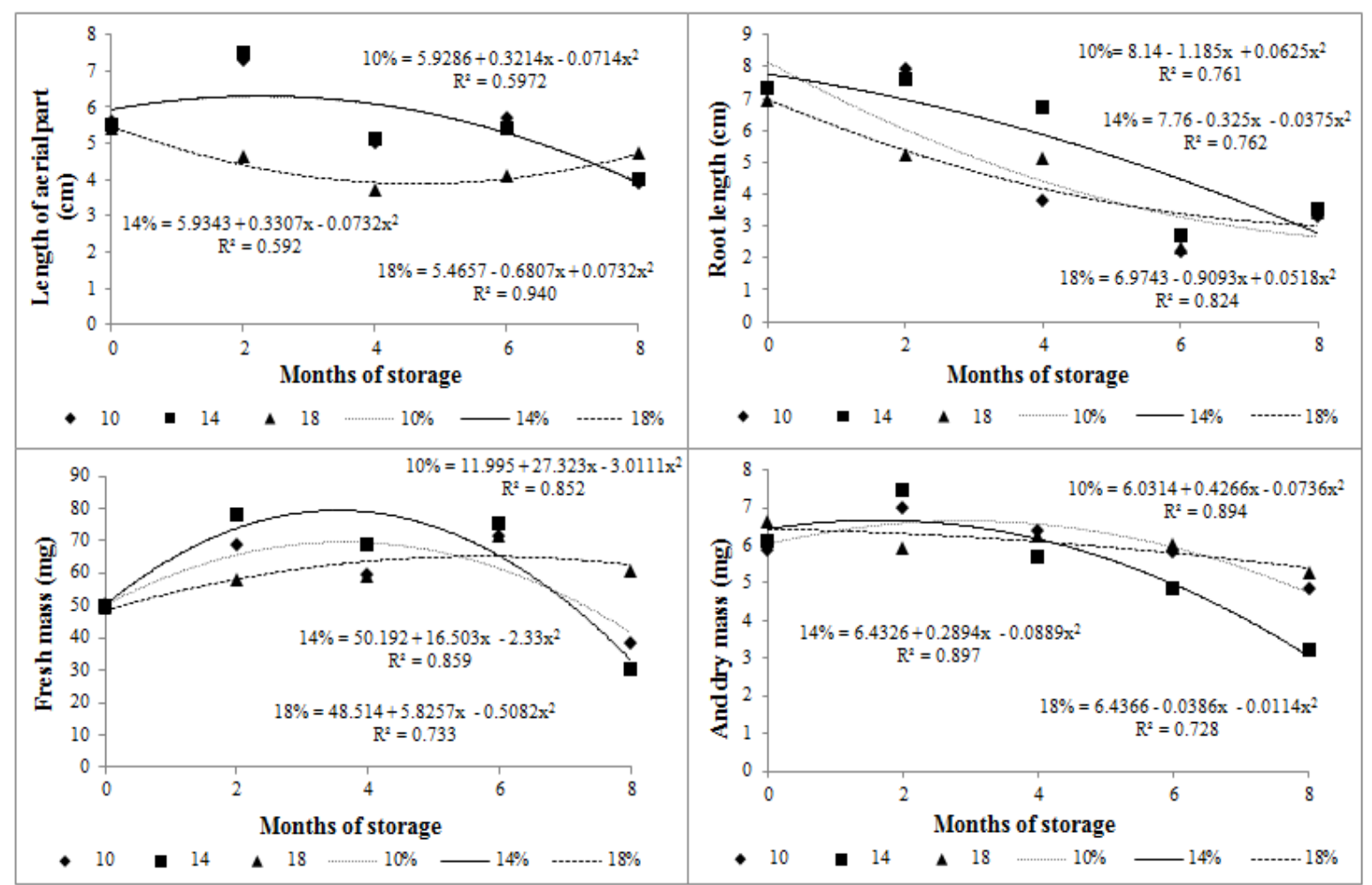

Fig 4. Length of aerial part, root length, fresh mass and dry mass of seedlings origining of seeds of Passiflora edulis Sims. $\mathrm{f}$. flavicarpa Deg., with water contents $10 \% ; 14 \%$ and $18 \%$, stored for eight months ( 240 days) of in and natural environment. 
progressive decrease in the germination speed, which is associated with the decrease in the seed vigour. Similar results were observed in jatropha seeds (Worang et al., 2008); beans (Silva et al., 2010); ipê-branco (Abbade and Takaki, 2014) and soybean (Smaniotto et al., 2014).

The storage time did not influence the shoot length, root length, fresh mass and dry mass of the seedlings in seeds stored in a cold chamber room with $10 \%$ and $14 \%$ water content (Figure 3). In contrast, Morais et al. (2014), when studying the vigour conservation of pinha seeds, observed that the storage time significantly affected the dry mass of the seedlings.

For seedling characteristics, the seeds stored for two months in a natural laboratory environment with $14 \%$ water content showed a higher mean in the length of shoot, root length, and fresh and dry mass of the seedlings. In addition, there was a decrease in the means of seedling characteristics after two months of storage (Figure 4).

\section{Materials and Methods}

\section{Plant materials}

The study was carried out in the Seed Analysis Laboratory of the Center of Agrarian Sciences and Engineering of the Federal University of Espírito Santo (CCAE-UFES), in the city of Alegre-ES, using yellow passion fruit seeds, the hybrid BRS Rubi do Cerrado - BRS RC (Passiflora edulis Sims. f. flavicarpa Deg.) from fruit harvested in orchards located in the southern region of the state of Espírito Santo, Brazil.

\section{Adjusting the seed moisture content}

The seeds of ripe and freshly harvested fruit were extracted with a sterilized spoon, and then the pulp was removed by extinguished lime, using a sieve. The seeds were washed in running water and kept on germitest paper roll for drying, adjusted to water contents of: $10 \% ; 14 \% ; 18 \%$ and $22 \%$ using humid chambers, and weighed periodically to adjust the water content to desired levels. Afterwards, the seed samples were submitted to germination and vigor tests, and the rest of the samples were placed in plastic bags of 0.10 $\mathrm{mm}$, sealed and placed in a cold chamber room at $4^{\circ} \mathrm{C}$ and a natural laboratory environment, $\pm 25^{\circ} \mathrm{C}$ without relative humidity and temperature control for eight months (240 days), being evaluated every two months:

\section{Physiological quality of the passion fruit seeds}

The seed moisture content - was determined with two replicates, by the greenhouse method, at $105 \pm 3^{\circ} \mathrm{C}$, for 24 hours, according to the instructions of the Rules for Seed Analysis (Brasil, 2009).

Germination - four replicates of 25 seeds for each treatment were produced, seeded on germitest paper rolls moistened with distilled water at a ratio 2.5 times the mass of the dry paper, kept in a BOD-type germination chamber, with alternating temperatures of $20-30$ 으, without the presence of light. The evaluations were held seven and 28 days after sowing, calculating the percentage of normal seedlings (Brasil, 2009), and the results expressed the germination percentage.
Germination speed index (GSI) - determined according to Maguire' methodology (1962), concomitant with the germination test, calculated daily on the number of seeds that had primary root protrusion equal to or greater than 2 $\mathrm{mm}$.

Length of aerial part - was determined 28 days after sowing, using a millimetre ruler, by measuring the length between the collar and the last leaf apex of ten seedlings, and the result expressed in plant ${ }^{-1} \mathrm{~cm}$.

Root length was determined 28 days after sowing, using a millimetre ruler, measuring ten seedlings from the neck to the tip of the largest root, and the results expressed in plant ${ }^{1} \mathrm{~cm}$.

The fresh and dry mass of the seedlings were determined 28 days after sowing in an analytical balance $(0.0001 \mathrm{~g})$. After the fresh mass was obtained, the seedlings were packed in kraft-type paper bags, kept in a convection oven at 72 o $C$ for 72 hours (constant mass), and the results expressed in plantula ${ }^{-1}$.mg.

\section{Study design and statistical analysis}

The experimental design was completely randomized, with two environments (cold chamber room $4^{\circ} \mathrm{C}$ and natural laboratory environment $25 \pm 2^{\circ} \mathrm{C}$ ) and with a plot experimental arrangement subdivided according to time, (plot: seed moisture contents $10 \% ; 14 \% ; 18 \%$ and $22 \%$, subplot: zero, two, four, six and eight months of storage), conducted with four replicates of 25 seeds within each environment. All statistical analyzes were performed using the software $R$ ( $R$ Core Team, 2017). The plot averages were compared by the $\mathrm{F}$ test at a $5 \%$ probability level and the Tukey test was performed, while the subplots were submitted to a regression analysis.

\section{Conclusion}

Yellow passion fruit seeds placed in a cold chamber room and natural environment with $14 \%$ water content present higher physiological quality during eight months (240 days) of storage. Yellow passion fruit seeds placed in a cold chamber room and the natural environment present maximum germination and vigour after 60 days of storage. Yellow passion fruit seeds exhibit orthodox behaviour, and should be stored at $14 \%$ water content in a cold chamber room and natural environment, without loss of viability and physiological quality, for eight months (240 days), presenting maximum germination and vigour after 60 days storage, without the presence of pathogens.

\section{Acknowledgements}

CAPES (Coordenação de Aperfeiçoamento de Pessoal de Nivel Superior) for granting a master's degree for the first author and CNPq (Conselho Nacional de Desenvolvimento Científico e Tecnológico) for granting a scholarship for the penultimate and last authors. 


\section{References}

Abbade LC, Takaki M (2014) Teste de tetrazólio para avaliação da qualidade de sementes de Tabebuia roseoalba (Ridl.) Sandwith - Bignoniaceae, submetidas ao armazenamento. Rev Árvore. 38(2):233-240.

Alexandre RS, Bruckner CH, Lopes JC (2009) Propagação do maracujazeiro: aspectos morfológicos, fisiológicos e genéticos. EDUFES, Vitória-ES, Brasil, 208p.

Antunes CGC, Pelacani CR, Ribeiro RC, Gomes HLR, Castra RD (2010) Influência do armazenamento na qualidade fisiológica de sementes de Caesalpinia pyramidalis Tul. Rev Árvore. 34(6):1001-1008.

Bessa JFV, Donadon JR, Resende O, Alves RMV, Sales JF,

Borges S, Borges EEL, Corrêa PC, Brune A (2009) Equilíbrio higroscópico e viabilidade de sementes de angicovermelho (Anadenanthera peregrina (L.) Speng) em diferentes condições ambientais de armazenamento. Sci For. 37(84):475-481.

Brasil (2009) Regras para análise de sementes, Ministério da Agricultura, Pecuária e Abastecimento, MAPA/DAS/ACS, Brasília, 395p.

Caetano GS, Sousa KA, Resende O, Sales JF, Costa LM (2012) Higroscopicidade de sementes de caju-de-árvore-docerrado. Pesqui Agropecu Trop. 42(4):437-445.

Cardoso RB, Binotti FFS, Cardoso ED (2012) Potencial fisiológico de sementes de crambe em função de embalagens e armazenamento. Pesqui Agropecu Trop. 42(3):272-278.

Carlesso VO, Berbert PA, Silva RF, Detmann E (2008) Secagem e armazenamento de sementes de maracujá amarelo (Passiflora edulis Sims. f. flavicarpa Degener). Rev Bras Sementes. 30(2):65-74.

Carvalho NM, Nakagawa J (2012) Sementes: ciência, tecnologia e produção. Jaboticabal: FUNEP, 590p.

Catunda PHA, Vieira HD, Silva RF, Posse SCP (2003) Influência do teor de água, da embalagem e das condições de armazenamento na qualidade de sementes de maracujá amarelo. Rev Bras Sementes. 25(1):65-71.

Cunha JPAR, Oliveira P, Santos CM, Mion RL (2009) Qualidade das sementes de soja após a colheita com dois tipos de colhedora e dois períodos de armazenamento. Cienc Rural. 39(5):1420-1425.

Forti VA, Cicero SM, Pinto TLF (2010) Avaliação da evolução de danos por "umidade" e redução do vigor em sementes de soja, cultivar TMG113-RR, durante o armazenamento, utilizando imagens de raios $X$ e testes de potencial fisiológico. Ver Bras Sementes. 32(3):123-133.

Goldfarb M, Queiroga VP (2013) Considerações sobre o armazenamento de sementes. Tecnol Ciênc Agropecu. 7(3):71-74.

Guzman LEP, Aquino AL (2009) Seed characteristics and storage behavior of physic nut (Jatropha curcas L.). Philipp $J$ of Crop Science. 34(1):13-21.

IBGE (2011) Produção agrícola municipal: produção de maracujá. Disponível em: <http://www.sidra.ibge.gov.br/>. Acesso em: 10 Fev. 2017.
José SCBR, Salomão NA, Costa TSA, Silva JTTT, Curi CCS (2010) Armazenamento de sementes de girassol em temperaturas subzero: aspectos fisiológicos e bioquímicos. Rev Bras Sementes. 32(4):29-38.

Lima PO, Lira LM, Lopes KP, Barbosa RCA (2010) Armazenamento de sementes de maracujá-amarelo. Rev Verde. 5(5):102-109.

Maguire JB (1962) Speed of germination-aid in selection and evaluation for seedling emergence vigor. Crop Sci. 2(2):176-177.

Marcos Filho J (2015) Fisiologia de sementes de plantas cultivadas. Londrina: ABRATES, $659 \mathrm{p}$.

Marques ER, Araújo EF, Araújo RF, Martins Filho S, Soares PC (2014) Seed quality of rice cultivars stored in different environments. J of Seed Sci. 36(1):32-39.

Martins L, Silva WR, Meletti LMM (2005) Conservação de sementes de maracujá-amarelo (Passiflora edulis SIMS F. flavicarpa DEG.). Rev Bras Sementes. 27(1):183-189.

Morais OM, Oliveira RH, Oliveira SL, Santos VB, Silva JCG (2014) Conservação do vigor de sementes de pinha Anonna squamosa L. Rev Árvore. 38(1):125-132.

Motta LB, Lopes JC, Zanotti RF, Bernardes PM, Silva JA (2014) Cryostorage of sunflower seeds. Biosci J. 30(2):312-319.

Popinigis F (1985) Fisiologia da semente. Brasília: AGIPLAN, $289 \mathrm{p}$.

Queiroga VP, Castro LBQ, Gomes JP, Jerônimo JF, Pedroza JP (2009) Qualidade de sementes de algodão armazenadas em função de diferentes cultivares e teores de água. Rev Caatinga. 22(4):136-144.

R Core Team. (2017) A language and environment for statistical computing. $\mathrm{R}$ Foundation for StatisticalComputing. Vienna, Austria,. Disponível em: http://www.R-project.org/, acessado em 20 dez. 2017.

Silva FS, Porto AG, Pascuali LC, Silva FTC (2010) Viabilidade do armazenamento de sementes em diferentes embalagens para pequenas propriedades rurais. Rev Cienc Agr Amb. 8(1): 45-56.

Silva MM, Souza HRT, David AMSS, Santos LMS, Silva RF, Amaro HT R (2014) Qualidade fisiológica e armazenamento de sementes de feijão-comum produzidas no norte de Minas Gerais. Rev Agroambiente. 8(1):97-103.

Smaniotto TAS, Resende O, Marçal KAF, Oliveira DEC, Simon G A (2014) Qualidade fisiológica das sementes de soja armazenadas em diferentes condições. Rev Bras Eng Agr Amb. 18(4):446-453.

Souza AD, Aoyama EM, Furlan MR (2015) Tempo e condição de armazenamento das sementes na germinação e desenvolvimento de Passiflora ligularis Juss. Rev Agr Amb. 8(1):181-192.

Vieira CV, Alvarenga AA, Castro EM, Nery FC, Santos MO (2008) Germinação e armazenamento de sementes de camboatã (Cupania vernalis Cambess.) SAPINDACEAE. Cienc agrotec. 32(2):444-449.

Worang RL, Dharmaputra OS, Miftahudin RS (2008) The quality of physic nut (Jatropha curcas L.) seeds packed in plastic material during storage. Biotropia. 15(1):25-36. 